The 49th Annual Conference of the International Association of School Librarianship

The 24th International Forum on Research on School Librarianship

July $12-16,2021$

Daniella Smith, Stacie Milburn, Diana Colby, Yildiz Esener, Diane Gill

University of North Texas

\title{
What Is Important for Survival?: The Analysis of a School Librarian COVID-19 Blog Post Corpus
}

\begin{abstract}
This paper examines blog posts shared on a popular school librarian association website. Posts were written by school librarians, school library supervisors, book authors, and school library educators in various settings. The website posts were searched using the term COVID-19. The search returned 89 results written between March 2020 and June 2021. The analysis focused on the topics that were mentioned the most, according to the categories associated with the blog posts. A review of how the posts evolved is also presented. Results suggest that the most important topics that the readers of the blog needed to endure the pandemic included student engagement, teaching models, leadership, and advocacy.
\end{abstract}

Keywords: COVID-19, Coronavirus, pandemic, school librarian disaster preparedness, school librarian professional development, school librarians, school librarian blogs

\section{Introduction}

Blogs are simply defined as an online forum where almost any subject can be discussed. The word "blog" originated from a shortened version of the weblog, which first existed on the internet in 1998 (Blood, 2000, para. 2). In the past, the blog was also referred to as an online journal with comments from readers, personal notes, and hyperlinks. Improvements and the everyday use of blogging to document stories led to the enhancement of this platform of expression. For example, blog post tagging and categorization were added to facilitate internet searches and the identification of dialogues relevant to the blog audience (Garrido-Marquez et al., 2018).

Like many other professional organizations, during the COVID-19 pandemic, the American Association of School Librarians (AASL) used its Knowledge Quest (KQ) blog to inform its members of updates in the educational community. In addition, the writers of the posts shared their experiences and provided advice about how school librarians could implement their roles while social distancing. In turn, these blog posts documented the experiences of school librarians who were rapidly adapting to a changing environment.

This paper explores the topics shared on the Knowledge Quest blog. We focus on how posts were categorized, who wrote them, and the posts that engaged the audience the most. A snapshot of 
how the posts evolved is also shared. Therefore, this study was designed to determine which subjects were the most important among the school librarianship community during the COVID-19 pandemic. This analysis of the blog posts can inform school library educators about how to adapt training for school librarians responding to contagions and health crises. As such, this paper's literature review includes a discussion of blog posts as corpuses for research and an overview of how they responded to the COVID-19 pandemic as evidenced by professional literature and research.

\section{Literature Review}

\section{Blog Posts as Research Corpuses}

Garrido-Marquez et al. (2018) discuss some of the benefits of using blogs for research. For example, blogs possess structured text and can be annotated and classified. Accordingly, researchers in the social sciences and humanities find them useful because a qualitative review of one or more blogs can identify the cognitive and communicative processes by which individuals create the identity of their blogs, relate to other bloggers, frame specific topics, and tell stories. Additionally, the analysis of blogs can illuminate how variation in the blogging process may be related to societal framings and values of specific areas of interest. Blog topics can also illuminate how factors such as socioeconomic backgrounds and other external or internal influences impact the perspectives of individual bloggers and their treatment of topics. Moreover, sociological studies of blogs have explored the practices and motivations of bloggers in relation to their locations. A wide variety of disciplines have used blogs in K-12 education and higher education to facilitate reflexive learning and discussion (Bruns \& Burgess, 2012).

According to Bruns and Burgess (2012), one of the most significant developments in blog research was the development of tools for the semi-automatic capture and analysis of extensive collections of Web-based content. Researchers can use automated Web crawlers that begin with a list of Web pages provided to them to collect and save blog posts as data. This process allows for in-depth analysis of blogs through textual analysis. This type of extraction is usually provided by a Web content scraper, i.e., software that takes a list of URLs and extracts the content of the web pages that is typically in HTML or plain text (Bruns \& Burgess, 2012). In the case of this study, a web scraper was programmed to gather the blog posts.

\section{Blogs as Professional Development Resources}

Using blogs for professional development is not a new process for teachers or school librarians. Teachers and librarians have been using blogs in education since the early $21^{\text {st }}$ century (Hong, 2008). Ferriter (2009) points out that blogs work for professional development because they meet two goals. First, they provide a collaborative space, and second, they utilize technology to connect learners. While most research on blog use for professional development focuses on teachers, school librarians utilize blogs similarly. With the use of technology, blogs allow educators to communicate, collaborate, and draw connections (Murugaiah et al., 2010; Zandi et 
at., 2014). However, in their small sample study, Dotson and Brown (2011) found that school librarians who participated did not take full advantage of using blogs for professional development.

By using blogs for professional development, educators can choose their professional learning, which leads to more engagement (Ferriter, 2009). Professional development needs to be small and continuous to impact the learner, and blogs allow for this bite-size learning. (Rybakova, 2015). Technology use and integration blogs are among the top blogs that help other educators and can be accessed at any time of need (Jackson-Brown, 2014; Moreillon, 2016; Rybakova, 2015). School librarian bloggers help with the professional development of their peers by focusing on different areas, including technology, literature, or other relevant topics (Jackson-Brown, 2014; Moreillon, 2016). Moreillon (2016) and Luo and Hostetler (2020) also point out that the benefits of blogs, including Twitter, i.e., microblogging, help librarians build their personal and professional learning networks.

\section{Statement of the Problem}

This brief literature review overviews how blogs can be used for professional development. Moreover, the literature review discusses how blog posts are documents that describe how society responds to events based on the stories that are shared within them. Because blogs facilitate storytelling and are often presented in order, they can be used as research corpora. As such, blogs have been studied in the social sciences, humanities, and education.

Although blogs are rich datasets, they have not yet been studied in the context of how the school library community reacted to the COVID-19 pandemic. Understanding the topics shared on the blog could provide essential clues about preparing school librarians for similar events in the future. This study examines the overarching question, "How did the school library community present on the AASL's KQ blog use posts to respond to the COVID-19 pandemic?" Other focus areas include the topics that were blogged about in the AASL KQ blog and the topics that were the most engaging to the readers. The following questions guided the implementation of the study.

Research Questions:

1. How did the number of posts evolve?

2. What KQ content categories were selected by the bloggers?

3. What type of school librarians and affiliated professionals contributed COVID-19 posts?

4. What posts received the most comments?

\section{Methodology}

Blog posts formed the corpus for the research study. The corpus consisted of posts made to the KQ blog between March 2020 and June 2021. A web scraper was programmed to search and collect posts that were labeled using the tag COVID-19. The search returned 89 results. The web scraper also collected details such as the date, KQ categories, numbers of comments, and author of each post. The posts were placed in a spreadsheet for analysis. 
Question 1 was analyzed using the month and year collected for each post. The months and years were then counted. KQ bloggers select the categories provided by AASL to label their posts. Question 2 used the content categories that were collected for each post. Question 3 was analyzed by first collecting the name of the author for each post. We then looked at each author's homepage for the KQ blog. Most authors had their affiliations listed. If they did not, we searched for them on the Internet to determine the type of affiliation that they had. The authors were then categorized according to their place of employment. For Question 4, we used the number of comments returned by the web scraper to answer the research questions.

\section{Findings}

\section{Research Question 1: How did the number of posts evolve?}

Figure 1 shows how the number of posts evolved. The two months with the most posts were April 2020 (14 posts) and March 2020 (10 posts). The two months with the least posts were June 2021 (5 posts) and June 2021 (5). The data for this paper was collected in the middle of June 2021. Therefore, it is logical that this month is one of the months with the fewest posts included. There were likely more posts added to the blog after the paper was written.

It is also understandable that the two most popular months for posts utilizing the COVID-19 tag are March 2020 and April 2020. These months likely represented the beginning of school districts' efforts to transition to social distancing and online learning. The KQ blog administrator requested that bloggers begin writing about COVID-19 around March.

The posts about COVID-19 increased again in September 2020 and October 2020, with both months having 8 posts each. The increase in September and October posts are typically months that represent the beginning of the academic school year. In preparation for the 2020 school year, authors wrote about leadership, creating inclusive environments, practicing self-care, access to online materials, and educating stakeholders about the roles of school librarians.

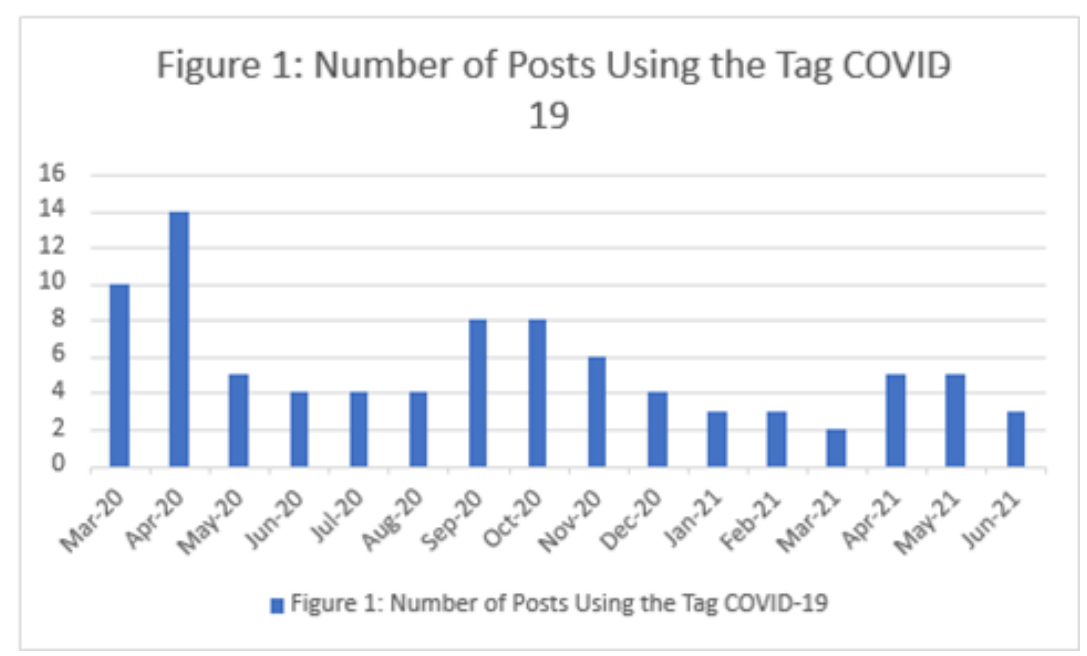

Research Question 2. What KQ content categories were selected by the bloggers? 
The KQ WordPress platform provides categories that bloggers can select to assist readers with finding their posts. In this question, we looked at the categories selected the most by the bloggers using the COVID-19 tag or keywords. The most important topic was Student Engagement/ Teaching Models (38) as indicated by the category selections of the authors. Student engagement/teaching models were followed by Advocacy/Leadership (35), and Community/Teacher Collaboration (24). Table 1 shows the distribution of the results and the wide variety of available tags for labeling posts.

Table 1:

Categories Selected by the Knowledge Quest Bloggers

\begin{tabular}{|l|c|}
\hline Selected Blog Categories & $\begin{array}{l}\text { Frequency } \\
\text { of Posts }\end{array}$ \\
\hline Student Engagement/Teaching Models & 38 \\
\hline Advocacy/Leadership & 35 \\
\hline Community/Teacher Collaboration & 24 \\
\hline Collection Development & 20 \\
\hline Professional Development & 20 \\
\hline Technology & 20 \\
\hline Community & 11 \\
\hline Diversity \& Inclusion & 11 \\
\hline Equity & 11 \\
\hline Awards Spotlight & 7 \\
\hline Association News & 5 \\
\hline News & 5 \\
\hline Pandemic Resource & 5 \\
\hline Intellectual Freedom & 4 \\
\hline Education News & 3 \\
\hline Makerspace/Learning Commons & \\
\hline College and Career & 2 \\
\hline
\end{tabular}




\begin{tabular}{|l|c|}
\hline College Preparation & 1 \\
\hline College Readiness & 1 \\
\hline Coronavirus & 1 \\
\hline COVID & 1 \\
\hline COVID-19 & 1 \\
\hline Information Literacy & 1 \\
\hline KQ Content & 1 \\
\hline Pandemic & 1 \\
\hline Pandemic Learning & 1 \\
\hline Presidential Musing & 1 \\
\hline Reading & 1 \\
\hline Remote Learning & 1 \\
\hline School Libraries & 1 \\
\hline STEM/STEAM & 1 \\
\hline Student Engagement/Teaching & 1 \\
\hline Volunteer & 1 \\
\hline Volunteering & 1 \\
\hline
\end{tabular}

\section{Research Question 3. What type of school librarians and affiliated professionals contributed COVID-19 posts?}

A variety of school library community members facilitated the discussion on COVID-19. These individuals included school librarians from all grade levels, AASL staff, school library educators, and supervisors. Book authors and other types of educators such as classroom teachers and consultants also participated. See Figure 2 for a list of the type of individuals who contributed posts and the number of posts they shared. The most active bloggers writing about COVID-19 were high school librarians (20). The following two most active groups were School Library Supervisors (17) and Library Educators (17). 


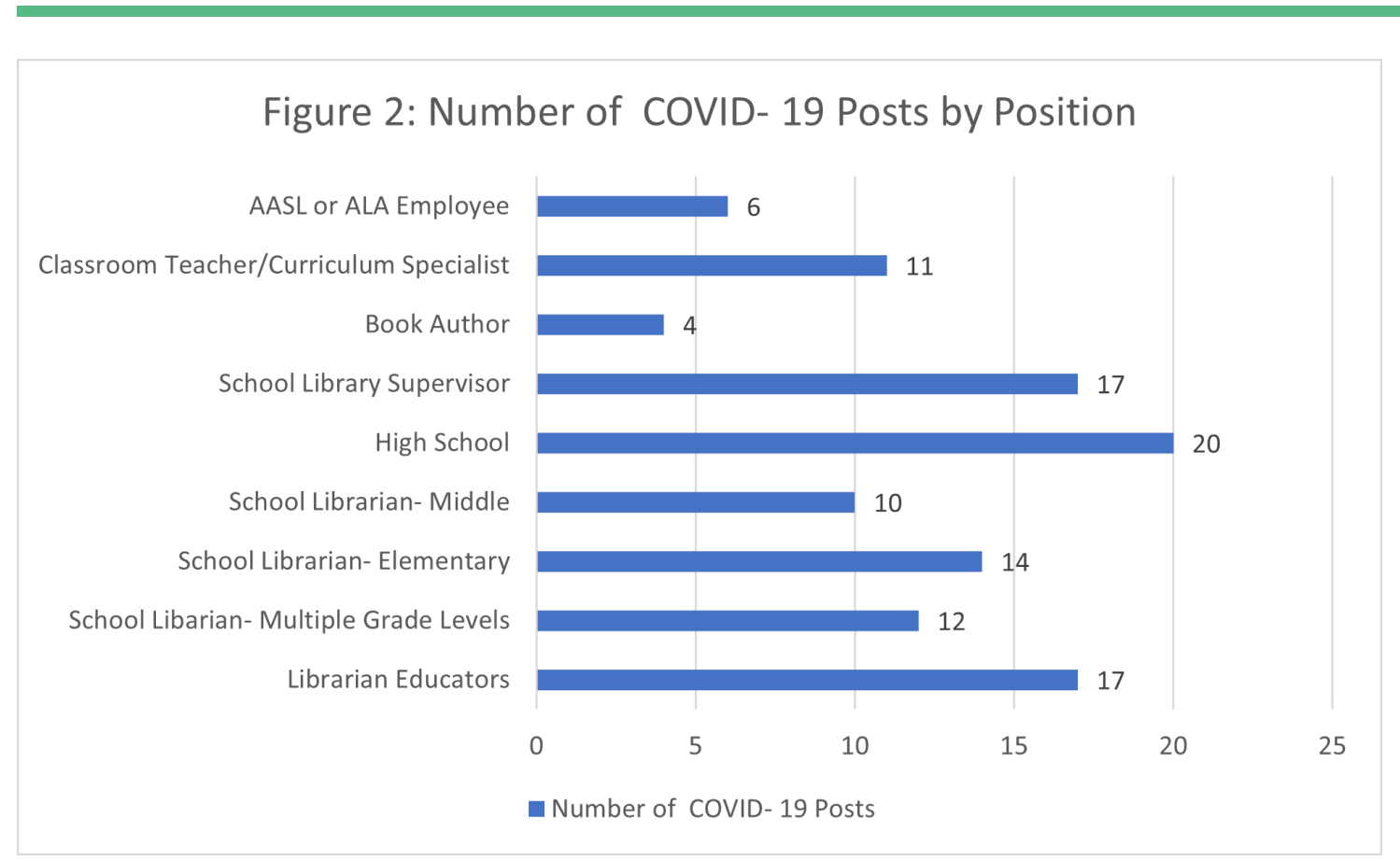

\section{Research Question 4: What posts received the most comments?}

Fewer than half (40) of the 89 blog posts received comments. The post with the most comments (18) related to implementing online school library services. The post with the second most posts (11) also talked about how school librarians could prepare for the pandemic. Most of the blog posts only had one or two comments. A complete list of the posts with comments are listed in Table 2. A chart (see Figure 3) revealed the most common categories selected. The words that emerge as the most prominent are student engagement, leadership, teaching models, and collaboration. Other categories that stand out are intellectual freedom, equity, inclusion, and diversity.

\section{Table 2}

Posts with Comments

\begin{tabular}{|c|l|}
\hline $\begin{array}{c}\text { Number of } \\
\text { Comments }\end{array}$ & Title of Post \\
\hline 18 & $\begin{array}{l}\text { The School Library Is Still Open! Ten Ways to Change Our Physical Spaces into } \\
\text { Virtual Libraries }\end{array}$ \\
\hline 11 & Pandemic Preparedness for School Libraries \\
\hline 6 & Leading Digital Escape Rooms Online during COVID-19 \\
\hline 6 & Distance Read-Alouds \\
\hline
\end{tabular}




\begin{tabular}{|c|c|}
\hline 4 & $\begin{array}{l}\text { \#infodemic: Why \#SchoolLibraries Are, More Than Ever, A } \\
\text { \#NecessityNotALuxury }\end{array}$ \\
\hline 3 & Tips for Applying to Doctoral Programs \\
\hline 3 & Pump Up the Volume! Boosting the Signal of School Librarians \\
\hline 3 & Safe Ways to Reach Students and Teachers While Social Distancing \\
\hline 3 & Conferences in a Pandemic \\
\hline 3 & $\begin{array}{l}\text { Serving Patrons during the Pandemic: Missouri School Librarians Rise to the } \\
\text { Challenge, Part I }\end{array}$ \\
\hline 2 & COVID-19 School Librarianship - Part 2 \\
\hline 2 & Avoiding Information Overload During COVID-19 Shelter-in-Place Orders \\
\hline 2 & Copyright Implications in the COVID-19 World \\
\hline 2 & It's School Library Month; Let the Celebrations Continue! \\
\hline 2 & \#NJASLSpring21, Part 2: Lessons from a Virtual Conference \\
\hline 2 & 5 Lesson Ideas with Picture Books and Laughter \\
\hline 2 & Access to Print Books? Yes! \\
\hline 2 & Rethinking the Notion of a School Library in a Time of Crisis \\
\hline 2 & When in Doubt, School Librarians Take the Reins \\
\hline 2 & Is That a Privilege? \\
\hline 2 & Changing Schools! \\
\hline 2 & School Libraries and Antiracism \\
\hline 2 & 7 Ways to Keep Kids Reading Even at a Distance \\
\hline 2 & Pandemic Journals: A Case Study in Online Lesson Collaboration \\
\hline 2 & School Library Month 2020 Celebrates School Librarian Resilience \\
\hline 2 & Add a Live Chat to Your Website \\
\hline 2 & Staying Connected with Students Despite Social Distancing \\
\hline 1 & Minding Mental Health during COVID-19 \\
\hline
\end{tabular}




\begin{tabular}{|l|l|}
\hline 1 & Chess, The Library, and The Queen's Gambit \\
\hline 1 & Updating My Collection via the Inspire Collection Development Grant \\
\hline 1 & Critical Thinking through Conspiracies \\
\hline 1 & Introduce Library Resources with a Challenge \\
\hline 1 & Reopening School Libraries: A Plan of Action \\
\hline 1 & Developing Inclusive Learners \& Citizens: A Call to Action \\
\hline 1 & Practicing Self-Care as Schools Reopen \\
\hline 1 & Library Leadership: A Seat at the Table \\
\hline 1 & Thoughts about Navigating Our Strange New World \\
\hline 1 & Behind the Scenes at NC's State Conference \\
\hline 1 & The Power of Positivity \\
\hline 1 & Journey with Jones: Leading Virtual Field Trips during COVID-19 \\
\hline
\end{tabular}

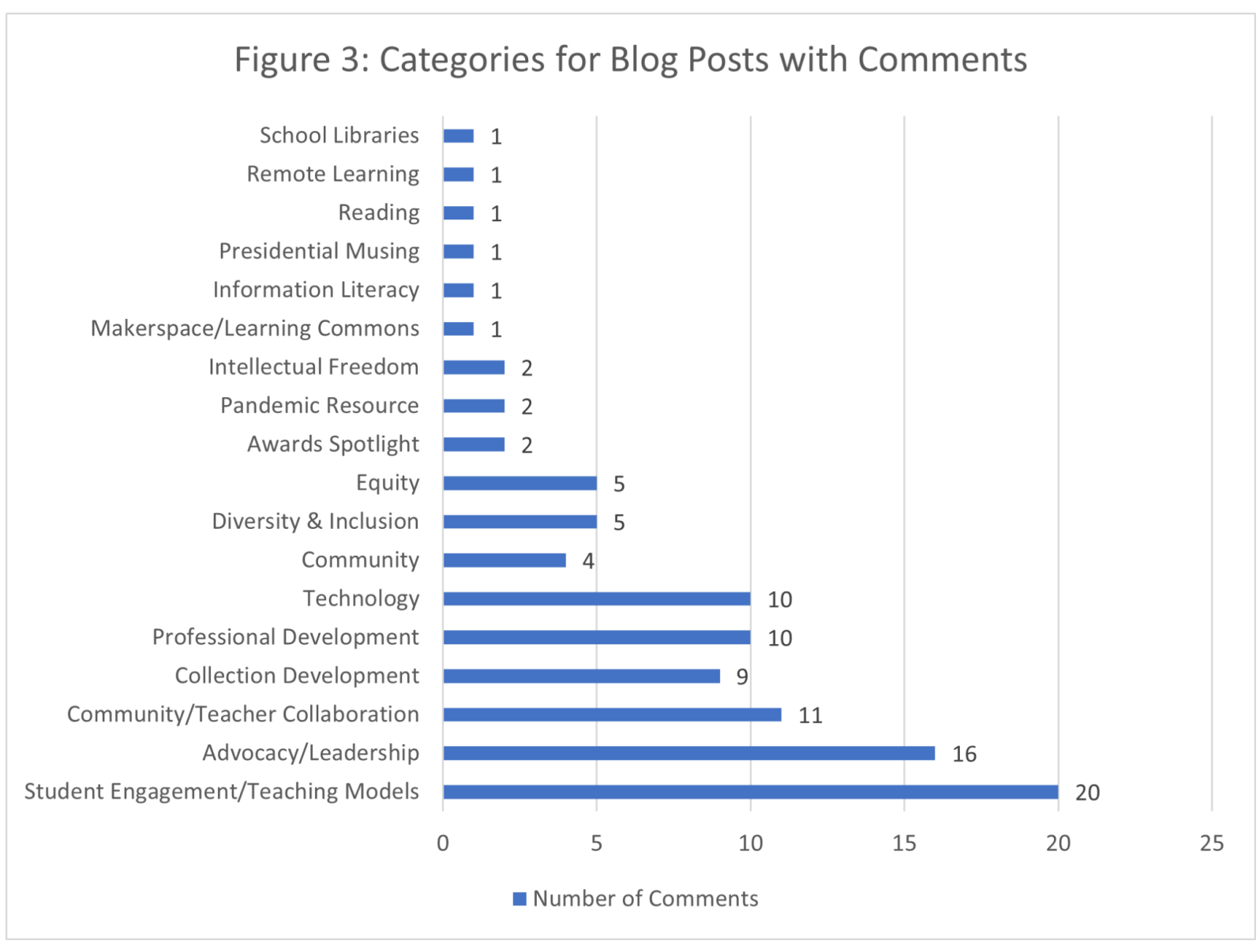




\section{Discussions}

\section{Changes in the Number of Blog Posts}

As expected, the posts made to the AASL KQ blog mimic trends occurring in the school library community. For instance, when schools began to contemplate how to adjust to the COVID virus, school librarians wrote to suggest strategies for providing access to their communities. As time went by, the frequency of posts started to decrease as they settled into their new norms.

In March 2020, many schools began to close because of the virus, and the changes necessitated more information sharing. Similarly, after the summer break, school librarians began preparing to return to the physical school environment after teaching online for months. Some schools were also tasked with functioning simultaneously online, and face-to-face as school districts offered parents options for student attendance. At that point, the posts increased again in September and October of 2020. There was another slight increase in COVID-19 posts when librarians began to prepare for the end of the school year in April and May of 2021. Garrido-Marquez et al. (2016) indicated that blogs could reveal what is happening at a particular time of history and reveal varying perspectives related to the importance of societal issues.

\section{Blog Categories as Indicators of Topic Importance}

The selection of post categories can illuminate how important topics are to the authors and readers of blog posts. In this study, the authors decided that the most important topics to address were student engagement/teaching models, advocacy/leadership, and community/teacher collaboration. Similarly, Figure 3 focused on the frequency of the categories for posts in which readers shared comments. The readers were highly engaged in the same top three categories. One can conclude that the authors focused on the categories that readers desired the most for professional development about the pandemic. Moreover, the match in the selection of topics and the categories that the readers commented on suggests that the bloggers are in tune with the audience's needs.

\section{Influential Voices in the School Librarianship Community}

The authors of the posts were collected and categorized according to their professional positions. Represented voices included the AASL staff, school library educators and supervisors, book authors, educators, and school library supervisors who contributed to the discussion on COVID-19 in school libraries. High school librarians produced the most content and were followed closely by school library educators and supervisors.

School library educators and supervisors are tasked with providing professional development for school librarians. Therefore, it is logical that they would submit many posts about strategies for coping with the pandemic. However, in the posts studied for this paper, we concluded that high school librarians had the dominant voice in the discussion. The frequency of the posts could be because there are more high school librarians writing for KQ than the other types of school 
library members. Alternatively, they may have dominated the conversation because high school students are closer to ending their kindergarten through $12^{\text {th }}$-grade education. While all primary and secondary education levels prepare students for college, students in secondary school are closer to entering college. Unfortunately, high school and secondary students are not aware of their information literacy skill deficits. These skill deficits have adverse effects on their ability to complete college coursework (Latham \& Gross, 2007). Hence, the results should be investigated further to clarify their meaning.

\section{Limitations}

This study only examined a small subset of blog material related to the school library community reacting to the COVID-19 pandemic. There is more content produced by independent school library community bloggers and organizations. For example, the School Library Journal has several posts written by school librarians that further illuminate how topics evolved and topics of interest during the time period. In addition, the bloggers for AASL's KQ blog submit their posts to an editor who may approve or disapprove of them. Therefore, some of the topics that the bloggers may have wanted to discuss may not be present on the blog. We chose to limit our search to COVID-19. Therefore, there may be posts on the blog that were missed. The web scraper is automated and could have missed results that a human performing a manual search would include. Finally, COVID-19 has many keywords that can be used to identify it. These keywords include COVID, coronavirus, and pandemic to program the web scraper.

\section{Conclusion}

In conclusion, we return to the title of this article. We asked, "What is important for the survival of school librarianship during a pandemic?" Based on the posts written by the school library community and its stakeholders and the community engagement with the posts, we have identified important factors for preparing school librarians for health-related disasters. Leadership, advocacy, student engagement, and collaboration with teachers and the community are essential components for success.

Leadership and advocacy are foundational concepts for school librarians who seek to engage their communities. A school librarian may lead as program administrators, collaborative partners, teachers, and information specialists. As noted by Jackson-Brown (2014) and Moreillon (2016), professional blogs (and microblogs) like the AASL KQ blog provided an opportunity for the school library community to collectively share their knowledge to overcome the obstacles presented by the pandemic. The librarians who wrote the posts focused on providing professional development when budgets did not provide for travel, and meeting face-to-face was ill-advised.

Therefore, this study reiterates that blogs are viable resources for professional development. Readers engage with them, and writers share a wealth of knowledge that covers a vast array of subjects. School library educators and district personnel can help school librarians prepare for future disaster situations by understanding and curating topics presented on the KQ blog. 


\section{References}

Blood, R. (2000, September 7). Weblogs: History and perspective Rebecca's Pocket. http://www.rebeccablood.net/essays/weblog_history.html

Bruns, A., \& Burgess, J. (2012). Doing blog research. In R. Coe, J. Arthur, M. Waring, M., \& L.V. Hedges (Eds.) Research Methods and Methodologies in Education (pp. 202-209). Sage Publications.

Dotson, K. B., \& Brown, C. A. (2011). Principles of effective professional development for school library leaders: The survey says. In M. Simonson (Ed.) $34^{\text {th }}$ Proceedings of the Annual Convention of the Association for Educational Communications and Technology (AECT): Vol. 1 (pp. 70-77). https://files.eric.ed.gov/fulltext/ED528860.pdf\#page=81

Ferriter, B. (2009). Learning with blogs and wikis. Educational Leadership, 66(5), 34-38.

Garrido-Marquez, I., Audibert, L., García-Flores, J., Lévy, F., \& Nazarenko, A. (2018). A French weblog corpus for new insights on blog post tagging. In A. M. Ortiz and C. Pérez-Hernández (Eds.), CILC2016 8th International Conference on Corpus Linguistics: Vol. 1. (pp.144-128). https://doi.org/10.29007/zcxp

Hong, W. (2008). Exploring educational use of blogs in U.S. education. US-China Education Review, 5(10), 34-38.

Jackson-Brown, G. M. (2013). Content analysis study of librarian blogs: Professional development and other uses. First Monday, 18(2). https://doi.org/10.5210/fm.v18i2.4343

Latham, D., \& Gross, M. (2007). What they don't know can hurt them: competency theory, library anxiety, and student self-assessments of their information literacy skills. Proceedings of the Association of College \& Research Libraries (ACRL) Thirteenth National Conference, USA.

https://www.ala.org/acrl/sites/ala.org.acrl/files/content/conferences/confsandpreconfs/nati onal/baltimore/papers/277.pdf

Moreillon, J. (2016). Building your personal learning network (PLN): 21st-Century school librarians seek self-regulated professional development online. Knowledge Quest, 44(3), 64-69.

Murugaiah, P., Azman, H., Ya'acob, A., \& Thang, S. M. (2010). Blogging in teachers' professional development: Its role in building computer-assisted language teaching skills. International Journal of Education and Development Using Information and Communication Technology (IJEDICT), 6, 73-87.

Rybakova, K. (2015). "The best kept secret in pedagogy": High school English teachers' use of educational blogs for professional development (Publication No. 3724356). [Doctoral dissertation, The Florida State University]. ProQuest Dissertations \& Theses Global.

Zandi, P., Thang, S., \& Krish, P. (2014). Teacher professional development through blogging: Some preliminary findings. Procedia - Social and Behavioral Sciences, 118, 530-536. https://doi.org/10.1016/j.sbspro.2014.02.072 

(n) 